\title{
"Philosophy of Biology"
}

Thomas Pradeu

(ImmunoConcept, UMR5164, CNRS \& Univ. Bordeaux; IHPST, UMR8590, CNRS \& Panthéon-Sorbonne Univ., France)

\section{in A. Barberousse, D. Bonnay and M. Cozic (eds.), Handbook in Philosophy of Science, Oxford University Press.}

Translated from French by Christopher Robertson

\section{Introduction}

"Philosophy of biology" refers to the critical examination of the conceptual, theoretical and methodological foundations of today's life sciences. Although biology, contrary to a mis-held notion, was not entirely absent from the logical positivists' preoccupations (Byron, 2007), philosophy of biology, as such, remains a recent field of study; for the most part its founders, practically all of them Anglo-Saxons, are still alive today. Important founders include David Hull (1935-2010), Michael Ruse (born in 1940), and Elliott Sober (born in 1948). A testimony to the influence of these founders, philosophy of biology has been dominated by questions about evolution, something which is still true today, as testified, in particular, by the contents of the main textbooks in the field (Sterelny and Griffiths, 1999; Sober, 2006; Rosenberg and McShea, 2008; Godfrey-Smith 2014). This situation is probably undergoing a slow change as interest in questions of molecular biology, developmental biology, microbiology and immunology become more and more established, but the domination of evolutionary issues in philosophy of biology remains extremely strong. Philosophy of biology has been particularly structured and institutionalized around one journal, Biology and Philosophy. Founded in 1986 by Michael Ruse, it was directed by him until 2000, when Kim Sterelny took over the reins.

Philosophy of biology has a paradoxical status. Its problems are unquestionably of a philosophical bent (e.g., "What is an individual?," "Does such a thing as human nature exist?," etc.), and yet it does not seem, not essentially at least, to be structured by the fundamental problems of philosophy of science (What is a theory, a law, a model? What is a scientific explanation? etc.) So, even though it has been one of the most active fields within philosophy of science since the end of the 1980s, philosophy of biology could seem to be little representative of general philosophy of science. For example, the textbooks of Sterelny and Griffiths (1999) and Sober (2006) mentioned above tackle almost none of the questions typically associated with general philosophy of science. At its outset, philosophy of biology was in equal measure built upon and also in opposition to the foundations of general philosophy of science. The building upon tendency is illustrated, in particular, by Ruse (1973), who applies traditional problems of the philosophy of science to biology, even placing himself in the continuation of logical empiricism, although sometimes with a critical attitude (see Hull's most enlightening analysis, 1977). The second, opposing, tendency is clearly apparent in Hull (1969, 1974), who is of the opinion that philosophy of biology must be built in large part in opposition to general philosophy of science of his time, seen as being excessively dominated by just one science, physics, and also, above all, by certain problems rooted in logical empiricism and an excessively analytical conception of philosophy of science, which Hull attacks for its idealistic views (Hull 1969, 1988, 1989b).

After the 1960s, philosophy of biology's autonomy with respect to general philosophy of science has tended to increase even further. Indeed, philosophy of biology has progressively broken free of the big questions of philosophy of science as its growing specialization has 
advanced. Of course, some influential philosophers of biology were really involved in general philosophy of science, or else had fields of interest that stretched beyond biology before becoming interested in the life sciences (see Rosenberg 1985; Sober 1984: ix-x). The latter have applied to the living world some classical questions of philosophy of science, notably questions about the theoretical status of the theory of evolution, or about reductionism. However, during the 1990s, a steady trickle of specialists in philosophy of biology began to appear who distanced themselves from general philosophy of science and its questions, while at the same time drawing closer to biologists. Kim Sterelny and Paul Griffiths are two typical examples of this trend in philosophy of biology. ${ }^{1}$

In this presentation, I hope to show the diversity of the problems posed in philosophy of biology by drawing attention to seven of them. The first, regarding the status of the theory of evolution, is undoubtedly the closest to typical questions from within general philosophy of science. Secondly, I will ask what is meant by the idea of adaptation in biology, when it is said, for example, that an organism is "well adapted" to its environment, or that an organ is "well adapted" to its function. This will lead us to a third problem regarding the basis biologists lean on when they turn to a functional and, seemingly at least, finalist vocabulary in speaking of an organ's or a trait's "function." Based on these first three steps, which will enable us to lay out several crucial aspects of the theory of evolution, we will consider the problem which has undoubtedly occupied philosophers of biology the most since the birth of their discipline, that is, the units of selection problem: Upon which biological entities (genes, genomes, cells, organisms, groups, species, etc.) does natural selection operate? Fifth of our problems, though evolution may be the dominant theme in philosophy of biology since its inception, the issues relative to organism development (by which is meant the changes an individual organism undergoes from its conception to its maturity - or, according to some, to its death) are in the process of establishing themselves as another major theme which we will analyze in turn. One of the objectives of research into development is to answer certain questions which the theory of evolution passes over, for example, questions concerning the legitimacy of speaking about a genetic programming of organism development and how the regulation of this development occurs. As we can see, the subject of development enables us to connect specifically evolutionary questions to those more tied in with cellular and molecular biology, these, in turn, being ever more studied by philosophers of biology. In the sixth section, we will look at the question of reductionism, which, within the context of contemporary philosophy of biology, primarily consists of asking whether or not it is possible to reduce macromolecular biology to molecular biology. In the seventh section, I will draw attention to some recent work that, contrary to the dominant trend in philosophy of biology, does not focus on evolution only. Following analysis of these problems, and by way of conclusion, I will come back to the question of the relationships held between philosophy of biology, general philosophy of science, and biology itself.

\section{The status of the theory of evolution}

The theory of evolution is generally considered to be the foundation to every proposition in biology, as well as the primary, if not unique, biological theory. What then, precisely, does "the theory of evolution" mean?

\footnotetext{
${ }^{1}$ This is how Sterelny and Griffiths lay out the approach they took in their manual Sex and Death: "One option would be to use biological examples to stalk general issues in philosophy of science - the nature of theory change, causation, explanation, and prediction. ... that is definitely not the book we have written. This book is very much focused and the conceptual and theoretical problems generated by the agenda of biology, rather than pursuing a philosophy of science agenda through biological examples" (Sterelny and Griffiths, 1999: xi). See also Sterelny (1995).
} 
The aim of the theory of evolution is to explain modifications in species over time; their adaptations and their diversification. Darwin was not the first to put forward an explanation for this phenomenon, nor to speak of species evolution (this idea can be found in Lamarck, in Erasmus Darwin, etc.). Nonetheless, Darwin (1859) advanced two decisive theories: common descent (captured in a species tree), that is, the assertion that today's organisms are descended from common ancestors; and natural selection, according to which there is a process of variation and then of differential survival and reproduction amongst organisms (the "struggle for existence" leading to the "survival of the fittest", to use the expression Darwin would eventually borrow from Spencer). So what we call the "theory of evolution" is a set of propositions initially put forward by Darwin and then, between the 1920s and 1950s, solidified around the central ideas of common ancestry and natural selection by those active in the "Modern evolutionary synthesis" (Mayr and Provine, 1980). However, as much in Darwin's case as in the case of the Modern Synthesis, speaking of the theory of evolution causes problems.

Firstly, can we truly speak of the theory of evolution? According to Mayr (1982), Darwin does not propose one but five theories: evolution as such, common descent, gradualism (the idea that species evolution occurs by means of cumulated minor modifications and not by "leaps"), population speciation (the idea of a continuity between population and species, a population of living creatures which undergoes variation being considered as a "nascent species"), and natural selection. Each of these theories met with a different fate. In particular, common ancestry was very quickly accepted by biologists following the publication of The Origin of the Species, while natural selection was neither well understood nor widely accepted in Darwin's own lifetime. Even though Darwin held to each of them, taken together they did not constitute a unified theoretical structure (Mayr, 1982). Furthermore, precisely as a result of this plurality of ideas in Darwin, they were on the verge of being abandoned at the turning of the $20^{\text {th }}$ century: following work which had rediscovered Mendel's "laws" of heredity, a certain tension arose between gradualism and speciation (Bowler 1983; Gayon, 1998). Darwin was in the dark regarding the mechanism behind variation in individuals, contenting himself to simply observe the phenomenon. But, to his eyes, it was clear that the variations were gradual and not saltatory. The first "geneticists" found the mechanism of variation in what they called "mutations" but, according to them, mutations were quite precisely leaps and not gradual modifications: for de Vries, in particular, species appeared suddenly following one of these mutations (Allen 1969). The Darwinian theory of gradualism and natural selection thus found themselves strongly rejected (Bowler 1983; Gayon, 1998). The first step of the Modern Synthesis (corresponding roughly to a period between the 1920s and 1930s) was the unification of genetics and Darwinism, primarily under Fisher's (1930) influence. Fisher showed that mutations, whose effects are generally limited, are perfectly compatible with Darwinian gradualism and in fact account for the variating mechanism so desperately sought since Darwin's day. It would, however, be erroneous to think that the Modern Synthesis lead to a unified theory of evolution. The second step of the Modern Synthesis (roughly from the 1930s to the 1950s) involved the aggregation of various disciplines of biology (zoology, botany, systematics, etc.) around a "solid core" of hypotheses (Mayr and Provine, 1980). So the Modern Synthesis came about more as a result of a sociological convergence (the unification of practically all the branches of biology on the basis of principles relative to evolution) than by the formulation of one theory of evolution (Gayon 1998: xiv).

Nevertheless, can we take the common principles all biologists have accepted since the Modern Synthesis and use them to deduce propositions for the "theory of evolution"? This leads us to our second question: can we really speak of a theory of evolution? Concerning Darwin's own ideas, we should perhaps speak not so much of a veritable theory as of a descriptive generalization which created a paradigm (in the sense of an exemplary model, widely imitated afterward) for understanding species evolution, at least in as far as common descent is 
concerned (Gayon, 1998). Nevertheless, it has often been emphasized (e.g., Ghiselin 1969; Lewens 2007a; Sober 2011) that Darwin had complied to the canons of theory construction of his time, and in particular to the views of Whewell and Herschel. Concerning the theory of evolution as it has been presented since the Modern Synthesis, philosophers of science have attempted to determine whether or not it constitutes a veritable theory. Many are the philosophers who have doubted its validity as a theory, their primary argument being that biology, since it is a "historical" science, cannot formulate laws, and hence cannot offer theories in a nomological sense (Smart, 1963; see also Beatty 1995). Most of Smart's arguments are invalid and rely on a false understanding of biology (Ruse, 1973; Hull, 1969, 1977): contrary to his claims, biology deals not with such and such albino mouse but with processes of a much wider scope, like the conditions for the expression of recessive genes, crossing-overs, the notion of geographically isolated populations, etc. - which all are processes about which generalizations are possible. On the other hand, it is undeniable that biological entities are spatiotemporally situated within an evolutionary history: for example, a biological species is a historical entity, the product of an evolutionary history, and not a class of objects open to abstract generalization which disregards spatiotemporal conditions, as is standard in physics. Consequently, formulating laws of biology, that is, general abstract propositions, at the level of historical entities, seems impossible. But for Hull, for instance, biology can formulate laws about entities that are not defined genealogically, in particular at levels of organization higher than particular taxa (Hull 1978: 353-354). From this point of view, the claim that biology could not offer laws at all is misleading (Hull 1976, 1978). It is, however, difficult to assess the scope of the claim that laws cannot be formulated about historical entities: in the context of that debate, doesn't physics run the risk of isolating itself from the majority of other empirical sciences, all "historical" in the sense we have defined, such as biology, geology, and the social sciences? If physics be the only science capable of formulating laws, should it remain a model for philosophy of science in general? Furthermore, certain branches of physics, like astronomy, also deal with historical entities. If the future reveals all empirical sciences to be "historical", wouldn't we have to soften our stipulation that a science must necessarily produce (spatiotemporally unrestricted) laws? Alternatively, we could suggest other, more "relaxed", conceptions of what a "law" is. Finally, the implicit assertion stating that a science cannot advance any theories once it advances no laws, must be handled with caution, as it depends on one particular vision of theories which, we shall now show, is not only not well suited to biology, but is also not the only vision of scientific theories possible.

In the 1970s, philosophers of biology brought precision to the debate around the problem of the theory of evolution's being a genuine theory or not by posing the following question: If the theory of evolution is a theory, is this in the "syntactic" or "semantic" sense of the term? According to the syntactic conception, best expressed by Hempel (1965), a theory is a hypothetico-deductive system in which, based on just a few axioms, one must be capable of deducing a large number of propositions. According to the semantic conception, defended in particular by van Fraassen (1972) and Suppe (see in particular Suppe 1977), a theory is a collection of models that must serve as the representation of empirical phenomena. In the semantic conception, to describe a theory is to present a class of models and to specify the manner in which those models reflect the phenomena. It quickly became apparent that the theory of evolution was not a theory in the syntactic sense of the term. Several biologists (M. B. Williams, 1970; Lewontin, 1970) and philosophers (Ruse, 1973) have attempted an axiomatization of the theory of evolution, but this has lead more to uncovering the theory of evolution's "structural core" than it has to a veritable axiomatization: by means of a method exemplified by Lewontin (1970), they pushed themselves to defining the minimal conditions a population of individuals must meet to be said to evolve by natural selection (for a fresh look at these questions, see Godfrey-Smith, 2007 and 2009). The most enthusiastic advocates for an 
axiomatization of the theory of evolution finally ended up showing that this effort could only be partial (M. B. Williams, 1981). Several philosophers of biology have defended the view that if the theory of evolution is a "theory," then it is so in the semantic rather than the syntactic sense of the term (e.g., Thompson 1983; Lloyd, 1988): it can be interpreted as a collection of models that must serve as the representation of empirical phenomena (important discussions of models in recent philosophy of biology, with a different perspective than that of Thompson or Lloyd, include Godfrey-Smith, 2006 and Weisberg 2006). Were a consensus to emerge regarding the semantic conception of scientific theories (but see Ereshefsky 1991), the oft repeated claim that the theory of evolution is not really a theory would have to be just as quickly flatly rejected. The work carried out by philosophers and biologists on the structure of the theory of evolution by natural selection since the end of the 1980s (e.g., Lloyd, 1988; Gould, 2002) sets its goal precisely as the clear definition of these models and the conditions for their testing.

\section{Adaptation}

According to many evolutionists, the aim of the theory of evolution is not so much to explain species modifications in general as the fascinating complexity of their traits and their amazing adaptation to their environment. The principal goal of the theory of evolution, in other words, would be in this view to account for adaptive complexity. Darwin (1859) himself stands behind this position ${ }^{2}$, which he illustrates through several examples, amongst which we find the recurring example of the woodpecker. In observing a woodpecker's beak, how could one not conclude that it was perfectly "adapted" to the bird's goal, which is to grab the insects from within the cracks in bark? For Darwin, and for many contemporary biologists as well, the question of adaptation can be viewed as being the "atheistic" inheritor of William Paley's natural theology: "The main task of any evolutionary theory is to explain adaptive complexity, i.e. to explain the same set of facts which Paley used as evidence of a Creator" (Maynard-Smith, 1969, p. 82). According to Paley (1802), a man going ashore on an island and finding a watch could not but deduce that the island was or had been inhabited, since such a complex artifact could not be the product of random chance; similarly, when we see a living being, its complexity (far superior to that of any artifact) is such that its origin in divine creation, and not random chance, cannot be doubted. Darwin, having eagerly taken the lectures on natural theology at Cambridge, takes on Paley's problem but asserts that it is a natural force without design, natural selection, which explains the adaptive complexity of living beings. Likewise, for Dawkins (1986), Paley poses the right problem, it's just that the watchmaker is "blind": natural selection is a force without design but which nevertheless explains the design-like appearance of things. In fact, natural selection appears as an optimizing force in respect to a given environment: when only the fittest survive and reproduce, natural selection explains the correct adaptation of organisms to their environment, right down to the most fascinating of consequences, like in the case of the woodpecker. It is also what the phenomenon of fixation illustrates, where an allele correlated to an advantageous trait goes from being rare to being ubiquitous (or "fixed") within a population. Of course, the adaptation process always depends on a given environment: when the environment changes, those organisms who were the best fitted to the previous environment will probably no longer be so with respect to the newly changed one. But as long as the environment remains relatively stable, adaptations resulting from natural selection can be transmitted along the generations.

The above passage could seem to be nothing more than a simple, uncontroversial description of the adaptive effects of natural selection. However, the adaptation debate has been

\footnotetext{
${ }^{2}$ Darwin describes his aim as to show "how the innumerable species inhabiting this world have been modified, so as to acquire that perfection of structure and coadaptation which most justly excites our admiration." (Darwin 1859 , Introduction).
} 
one of the most charged areas in philosophy of biology since the 1970s. Given that the terms of this debate have not always been sufficiently clear, I will try to define adaptation and its related concepts as best as possible before presenting the bases of attacks on "adaptationism" (adaptationism, analyzed further on, is the position stating that living beings, thanks to natural selection, are perfectly adapted to their environment).

How should the concept of adaptation, seeming at once central to the theory of evolution as well as reliant upon a firmly intuitive interpretation, be defined? Taking our lead from Lewens (2007b), we can begin by envisaging an informal definition of adaptation: an adaptation is just a trait which seems guided towards a design but whose existence is in fact the result of natural selection (G. C. Williams, 1966; Dawkins, 1986). However, a definition like this excessively hangs the notion of adaptation on Paley's theological outlook: it seems quite unacceptable to suggest that the identification of adaptations depend upon a discipline which is unanimously viewed as unscientific and whose clearest echoes are found in the modern thesis of "intelligent design". To more precisely and more robustly determine what adaptations are, Sober (1984: 208), picking up from Brandon (1978) and Burian (1983), proposed an explicitly historical definition: " $A$ is an adaptation for task $T$ in population $P$ if and only if $A$ became prevalent in $P$ because there was selection for $A$, where the selective advantage of $A$ was due to the fact that $A$ helped perform task T." An adaptation is thus a trait whose presence and persistence within a given population is the result of its contribution to the overall fitness of the organisms that possessed this trait in the past (it is, therefore, important not to confuse adaptation and fitness, as the remainder of this section shall show in detail). This definition may seem circular: it would seem difficult to accept that the Darwinian revolution consisted of explaining adaptation by means of natural selection if adaptation were to be defined as the product of natural selection. However, the circularity vanishes when we assert that Darwin meant for traits such as the vertebrate eye or the woodpecker's beak, and for behaviors such as certain instincts to be seen as the consequences of natural selection's specific action. In an equivalent but more precise manner, the Darwinian position can be reformulated by saying that Darwin showed how the "correct adaptation" of living beings towards their present environment is explained away as being the product of the past actions of natural selection. Even though a non-historical definition has been put forward, stating that an adaptation, in the present, is, "a phenotypic variant that results in the highest fitness among a specified set of variants in a given environments" (Reeve and Shermann, 1993, p. 9) ${ }^{3}$, the historical definition is nevertheless the dominant one (Brandon, 1990).

On the basis of this historical definition, philosophers of biology have proposed several useful conceptual distinctions for understanding adaptation. The most important is that between an adaptation, a trait selected in the past because it increased the fitness of its bearer, and an adaptive trait, a trait that increases its bearer's fitness in the present. An adaptive trait is not necessarily an adaptation, and vice-versa. Imagine, for example, that the woodpecker's beak presently enables it to nest in drain pipes and that this increases its fitness: this would be an "adaptive trait" but not, however, an "adaptation" in the historical sense, that is, the product of repeated natural selection in the woodpecker species' past. Conversely, very thick plumage in certain woodpeckers could be the product of natural selection's past action and yet no longer be "adaptive" in a climate where the temperature had increased significantly. Similarly, the distinction must be made between an adaptation, the result of a process (the woodpecker's beak, for example), and adaptation in the general sense, that is, the process that lead to this result itself. In most cases, philosophers of biology have the result, and not the process, in mind. What precedes illustrates the fundamental difference between the concepts of adaptation and of

\footnotetext{
${ }^{3}$ In this definition, a "phenotypic variant" refers to a particular trait possessed only by a subset of living beings of a given species (for example, those woodpeckers who possess a much stronger beak than their kin), in a given environment.
} 
expected fitness: the mechanism of natural selection probabilistically predicts that individuals with higher fitness will survive and reproduce, while adaptation is the name given to the result of the immediate selection process. The definition of adaptedness (Brandon, 1990) enables us to highlight the non-tautological character of the natural selection hypothesis: this is not worded to say that the fittest survive by defining the fittest as those who survive, rather it defines those traits which increase the probabilities of survival and reproduction in those who possess them (Mills and Beatty, 1979). The consequence of this is that those individuals with the highest expected fitness (Burian, 1983; Brandon, 1990 refers to adaptedness) may not necessarily be those who survive and reproduce the best, that is, who display the highest realized fitness.

Let us look now at some criticism "adaptationism" has received. In what has remained one of the most famous articles in biology and philosophy of biology over the last decades, Gould and Lewontin (1979) denounced this adaptationism, that is, biologists' "panglossian" attitude, which, like Voltaire's Pangloss, sees every biological trait as proof that all is for the best in the best of all possible biological worlds. Gould and Lewontin, using numerous examples, show that this attitude is extremely widespread in the biology of their time. In their view, adaptationism occurs in two steps: 1) the atomization of the organism into traits, each of which is described as a structure optimally conceived for its "function" by natural selection; 2) each trait seeming, in fact not to be perfectly adapted to its function, the adaptationist explains that each organism is the best trade-off possible between the different environmental demands to which it is subjected. Dennett (1995), without doubt the most audacious or, depending on one's own opinion, most naive of the adaptationists, openly admits this "panglossianism," which he believes to be inherent to the argument for natural selection (on this matter, see also Dupré 1987).

In reality, the criticisms drawn together by Gould and Lewontin seem today to be as passionate as they are insufficiently unraveled. Here, aligning myself in part with the remarkable clarifications put forward by Godfrey-Smith (2001) and Lewens (2009), I distinguish three overlapping problems in their article.

1) Is natural selection the only, or even the primary, evolutionary mechanism? Clearly, natural selection is not the only mechanism of evolution: random genetic derivation (that is, modification due to random sampling of allelic frequencies from one generation to the next for a given population ${ }^{4}$ ), in particular, plays an important role in species evolution, especially in cases of small population sizes. Other evolutionary mechanisms are also acknowledged by many biologists (allometry, for example, i.e. the correlation between the size and the shape of an organism). Gould and Lewontin insist upon development constraints and upon the "Baupläne" which limit natural selection's action possibilities and thus innovation. Darwin himself vehemently asserted that natural selection was the primary but not the only evolutionary mechanism (see, in particular, a famous letter of Darwin, published in Nature: Darwin 1880). In asserting that natural selection is not the only mechanism of evolution, Gould and Lewontin can rest assured that all biologists will agree with them. However, the authors add that, at time of writing, these other mechanisms of evolution had not yet drawn sufficient attention, something which was undoubtedly true in 1979 but we can affirm is less so today (especially since Kimura, 1983). Most importantly, Gould and Lewontin pose two real problems which still remain pertinent now: 1) What exactly are the other mechanisms of evolution?; 2) Which part of evolution must be attributed to each mechanism (selection, derivation, etc.)?

\footnotetext{
${ }^{4}$ Imagine a population of woodpeckers. The allele A (possessed by woodpeckers with a very strong beak) has a frequency $p$. The frequency of this allele A in all possible descendant populations of woodpeckers will average $p$. However, the realized woodpecker descendants constitute only a sample selection from within these possible descendants, so that the actual realized frequency of allele A could, in fact, differ to $p$. Thus, independently of the effects of natural selection, the frequency of a given allele changes from one generation to another simply by the effect of random sampling.
} 
2) Do mechanisms other than natural selection enable explanation of adaptive complexity? In their criticism of adaptationism, Gould and Lewontin do not sufficiently differentiate this question from the previous one. If their position in respect to (1), where they affirm that natural selection is not the only adaptive mechanism, seems, today at least, to meet with consensus, with this second question they place themselves in opposition to the great majority of biologists (first among these being G. C. Williams, Dawkins, and Maynard-Smith). Gould and Lewontin show that the "correct adaptation" of organisms to their environment can sometimes be explained by other mechanisms than natural selection, like phenotype plasticity, for example (what Mary-Jane West-Eberhard more recently describes as "the ability of an organism to react to an environmental input with a change in form, state, movement, or rate of activity"; West-Eberhard, 2003, p. 34). The difficulty lies in precisely demonstrating in what measure these mechanisms are indeed evolutionary, that is, liable to ancestral transmission, making possible the accumulation of adaptive effects down through the history of the species, rather than their just being processes involving only the individual (ontogenetics). Gould and Lewontin do not sufficiently rise to this but, once again, recent work is carrying their intuitions forward by showing, notably, the evolutionary effects of phenotypic plasticity (West-Eberhard, 2003). Another, partly related possibility is epigenetic adaptation (Jablonka and Lamb 2005). As of yet, no consensus has emerged on these matters. For now, the vast majority of biologists deem that, if adaptive complexity is what we are trying to explain, then the best explanation available to us is certainly natural selection (though see West-Eberhard, 2003 and Müller, 2007).

3) Must every biological trait be explained in terms of adaptation? In my view, this is the heart of Gould and Lewontin's article. This third question is obviously linked to the first two, but it is important to point out how it is distinct from them also. The first question is rightfully removed from the question of adaptation itself, being rather concerned with the problem of natural selection's importance in evolution. The second question, by contrast, contains the admission that adaptation is a fundamental biological phenomenon, therefore necessitating explanation, and asks if the best explanation for adaptation is the mechanism of natural selection. In the third question, the idea that one of the most fundamental characteristics of living creatures is their "adaptation" is challenged and, along with it, the claim that one of biology's primary tasks is to explain this adaptation. To use one of Gould and Lewontin's most famous examples, many biologists state that the existence of the Tyrannosaurus' small sized forelimbs is a puzzle: what purpose could possibly be served by limbs so short they don't even reach the mouth? What could their "function" have been? Gould and Lewontin respond that relentlessly seeking a solution to these limbs' "adaptedness" to nature may be of little benefit: i) they must first and foremost be seen as being inherited from organs existing in the Tyrannosaurus' ancestors; ii) present usefulness and adaptation, in the sense of "product of natural selection", must not be confused (in this they agree with the point established above). In other words, Gould and Lewontin maintain that a great many biological traits are not "well adapted". The dominant interpretation is that Gould and Lewontin's article is merely a useful, though little consequential (in terms of actual biology) warning against the excesses of seeing adaptation everywhere. And yet, in reality, the article contains far more than that (GodfreySmith, 2001), particularly when it is seen in relation to Lewontin's argument that the construction metaphor must replace the adaptation metaphor in contemporary biology (Lewontin, 1978; this argument has recently seen a highly remarkable, though sometimes contested, resurgence in interest in the wake of Odling-Smee et al., 2003): he proposes research avenues to biologists for the exploration of processes other than just adaptation in the practice of biology, as well as for new perspectives on the living world.

To conclude this section, I come back to the most fundamental question. Is adaptation the most important element of the living world, that which biology must therefore explain as a 
priority? Joining Gould and Lewontin, we seem in our right to be doubtful. What is certain is that those supporting this proposition must put forward far more solid arguments than those which have thus far been formulated, of which Dawkins' (1986, p. 303) is the most typical: "Large quantities of evolutionary change may be non-adaptive, in which case these alternative theories may well be important in parts of evolution, but only in the boring parts of evolution..." Not only could the exact contrary be asserted but, in any case, the argument of the scientific interest bears no weight when dealing with a question about the reality of the living world (Godfrey-Smith, 2001). As Lewens (2007b) shows, the fact of many biologists focusing on the phenomenon of adaptation seems, in reality, to be largely evidence for the genealogy of the Darwinian theory, itself stemming from Paley's natural theology (this includes the likes of Dawkins, Dennett, Grafen, Maynard-Smith, etc.). It may well be doubted that there exist one fundamental question in biology. As for evolutionary biology, if we had to ascribe just one fundamental question to it then, following Ghiselin (1983), this would be, "What happened?", that is, "What is the history of life?", and not the riskier, and indeed very problematic, "How can life's amazing adaptation be explained?".

\section{Functions and teleology in biology}

Contrary to physics or chemistry, biology seems to employ a teleological vocabulary: do we not say, for example, that the "function" of the heart is to circulate blood, or that the heart is "for" circulating blood? The question arises of how such statements should be understood, and whether or not the presence of teleological vocabulary is problematic in an experimental science such as biology.

Nagel (1961) considered the use of teleological vocabulary to be a serious obstacle should biology wish to gain real scientific legitimacy, compared to the example of physics which had slowly but surely freed itself of teleology. He also suggested replacing functional statements with ordinary causal statements, interpreting cause as necessary condition. For example, the expression "the function of the heart is to circulate blood" would have to be replaced by the expression "the heart is a necessary condition for the circulation of blood". However, as shown by Larry Wright in a founding article (1973), this suggestion fails because it does not allow for the distinction of two cases that biologists imperatively wish to distinguish. For example, hemoglobin is at once a necessary condition for the redness of blood as well as for the transportation of oxygen; nevertheless, biologists will state that its "function" is to transport oxygen, never that it is to give blood its red color. In other words, while Nagel had perfectly exposed the problem, unfortunately his solution didn't fit.

Philosophy of biology, largely relying on philosophy of mind, has enabled decisive progress on the question of biological functions. This progress has lead to what could be called, following Godfrey-Smith (1993), a "consensus without unity," in light of the fact that two clearly distinct uses of the term "function" exist in biology today, the etiological and the systemic uses. This distinction has clarified the functions debate considerably.

According to the etiological conception, of which Wright (1973) and Nedander (1991) are among the principal representatives, the statement "the function of the heart is to circulate blood" means "the heart was selected in the past for its capacity to circulate blood." This conception is, on the one hand, fundamentally historic and, on the other hand, immediately correlated to the idea of adaptation by natural selection met in the previous section: a function is any trait which is the product of its positive contribution, in the past, to the fitness of the members of a species. The etiological conception seems to dominate in the function debate, the majority of philosophers of biology of the last twenty-five years or so having aligned themselves with it. One of the most notable is Karen Neander who has proposed defining a function, quite simply, as a "selected effect" (Neander, 1991). One of the main reasons for the success of this conception is that it seems to meet the demand for a "naturalization" of the 
teleological wording found at the center of philosophical reflection on functions. For example, Gayon (2006, p. 482) writes: "When the biologist uses the notion of function, his interest is not only in the actual effect of some apparatus or process. He is not only occupied with what it does, but also with what it is supposed to do." The etiological conception defines a functional norm relative to a certain type of organisms (for example, all vertebrates or all zebras, etc.); in so doing, it allows for the assertion that a heart which does not fulfill the function for which hearts were selected therefore does not function "normally": it doesn't do what it is "supposed to do." One of the possible objections to the etiological conception is that it may run the risk of a certain "adaptationism" if it begins to see all traits as "functions". However, this is only a possible, rather than a necessary, consequence of the etiological conception. Another objection to this conception is the difficulty it has, with its own specific vocabulary, in accounting for the "adaptive" character of an innovation: a newly appeared trait increasing the fitness of its bearer (and, in the future, of its descendants) cannot be said to have a "function", in the etiological sense, since it is not the product of an evolutionary history. Nevertheless, it is likely that biologists would still choose to speak of this as a "function". And yet, a simple conceptual clarification, such as that between adaptation and adaptive trait, could probably dissipate this difficulty.

The second conception, called the "systemic" conception, differs greatly, because its eye is not on the past, and it is not reliant on the theory of evolution by natural selection. The systemic conception is founded on the present analysis of a biological mechanism. According to Cummins (1975), functions are not effects that explain why something is there, but effects which contribute to the explanation of more complex abilities and dispositions within a system they partake in. In other words, Cummins' starting point is the delimitation of a biological "system", the organism being available to analysis within several systems (circulatory, nervous, respiratory, etc.), themselves divided into characteristic capacities which, in turn, can be analyzed as organs and structures participating in the realization of that ability. For example, in speaking of the respiratory system, we can talk of its capacity to transport food, oxygen, waste, etc., and, in the context of that systemic capacity, we can say that the heart is capable of pumping, which means that this is its "function", in the systemic sense of the word (Cummins, 1975, p. 762). The systemic conception offers the advantage of being equally applicable to living beings as to artifacts or technical systems, with Cummins even proposing that biological functions be understood following the analysis model for the functioning of an assembly line. Furthermore, in assuring that one and the same function can be accomplished by various structures having diverse evolutionary histories, it accounts for the fundamental difference struck in biology of evolution between homologies (organisms having similar traits due to their common genealogical origin) and evolutionary convergences (similar traits not due to a common genealogical origin).

The systemic conception prolongs and enriches what Mayr (1961) advanced under the title of "functional biology" - that part of biology which poses "how?" type questions, in opposition to the biology of evolution which poses "why?" type questions. This explains that the systemic conception dominates physiology and experimental biology. As for the etiological conception, it is situated exactly on the evolutionary biology side ("why?" questions). It must, however, be made clear that within the context of the debate on biological "functions" the term "functional biology" must be avoided, since it sweeps away the distinction between the systemic and etiological conceptions.

The systemic conception is not teleological, it accounts for the causal contribution of a mechanism to a system it forms a part of, it does not attempt to say what ends traits have, nor what they are "supposed to do". It is therefore "mechanistic", one of the possible extensions of that conception being precisely the recent interest in philosophy of biology for the notion of mechanism (Machamer, Darden, Craver 2000; Craver, 2007; Bechtel 2005). Consequently, it 
does not answer the demand often formulated with regard to the notion of function, the question of what something is "supposed to do." For this reason, the systemic conception often meets with the same criticism that Nagel had already faced: not accounting for the normativity of the notion of function, nor, correlatively, for the possibility of dysfunction. This is undoubtedly the most serious objection that can be leveled at this conception, though it is unlikely to be a fatal one. First of all, quite simply, we cannot criticize the systemic conception for not doing precisely what it wishes to not do, namely, giving an answer to the question of what a trait is "supposed to do" (Cummins, 1975, p. 757, footnote 13). Secondly, some dysfunctions at least can be understood "systemically", for example when we analyze a disease as a series of causal contributions to the overall effect on the system. In this way we can, for example, explain the development of an autoimmune disease by saying that it results from a dysfunction of the immune system (which in these cases stops performing what is generally considered to be its function - defending the integrity of the organism), but we can also explain it by detailing the cellular and molecular mechanisms which lead to this pathological state - by showing, for example, in what way the number of regulatory cells in the organism have decreased, why there is cross-matching with a pathogen, etc. (Pradeu 2010a). Additionally, the systemic conception may resort to a statistical definition of norms, where what is normal would be defined simply as what is the most commonly occurring.

Finally, it appears that both conceptions are operational and that each of them is dominant within one or the other of the two main branches of biology (evolutionary biology and "mechanistic" biology, in the broad sense). It may be deemed regrettable that the term "function" find itself split into two such different meanings. Some philosophers have attempted to bring these two meanings for "function" together under one single definition. The most remarkable of these attempts is Kitcher's (1993), who proposes uniting them under the umbrella concept of "design". However, his attempt did not convince Godfrey-Smith (1993), and it can in fact be claimed that one of the most clear advancements due to philosophy of biology is the firm assertion that there does exist two distinct concepts of function. In the interests of complete clarification, it would perhaps be useful to reserve the term "function" for just one of the two ideas analyzed here, though such a reform of functional vocabulary seems unlikely given that, on the one hand, biologists are quite firmly attached to it and that, on the other hand, few actual incompatibilities between them have arisen.

\section{The units of selection debate}

Unquestionably, the most intense and impassioned of all debates in philosophy of biology these last forty years has been the units of selection debate. To a lesser, yet still considerable, degree it has also drawn in the biologists themselves. With hindsight, it could be said that the fierce tensions identified with it were at least partly created by a lack of clarity in the initial wording of the problem. The most significant contributions to the debate have come from biologists but the most important clarifications were the work of philosophers.

The starting point is the aforementioned problem with the structure of the theory of evolution by natural selection (TENS). Following on from Mary Williams' (1970) work, Lewontin (1970) showed that the structure of the TENS made it applicable to a wide variety of entities, and not to organisms only: any population made up of entities characterized by variation, differential fitness and the heredity of that fitness can be said to evolve by natural selection. Lewontin's question, in what was the first text entitled "Units of selection", is this: "Which entities are capable of evolution by natural selection?" His response covers a wide spectrum, not only individual organisms, as is generally asserted, but also a whole hierarchy of biological entities: genes, organelles, cells, organisms, populations, species, even as far as ecosystems and prebiotic molecules (see also Lewontin 1985). 
In publishing The Selfish Gene, Dawkins (1976) set the debate on units of selection into full swing, in the sense that, from that point onwards, huge numbers of biologists and practically every philosopher of biology felt the need to have their say on the matter. Dawkins' thesis, inspired by the views of George Williams (1966), Hamilton, and, in part, by certain actors of the Modern Synthesis (Mayr 2004), is called "genic selectionism" or the "gene-centered view of evolution". Dawkins is largely responsible for the confusion which reigned over this debate for several decades because he uses the same term as Lewontin, i.e., "unit of selection", despite their dealing with completely different problems. Dawkins' question is: "To whose benefit does natural selection occur?" For Dawkins, genes are the real units of selection as they are the real beneficiaries of natural selection and its effects. His argumentation can be summed up in four steps: i) the most important biological phenomenon, adaptive complexity, can only be understood over long evolutionary periods of time; ii) however, placed beside such lengthy time periods, organisms are very ephemeral beings, they are, as famously suggested by Dawkins, "like clouds in the sky or dust-storms in the desert" (Dawkins, 1976, p. 34); iii) in contrast, the genes contained within these organisms are transmitted between generations with great fidelity, they are what truly persist on the evolutionary scale, making the accumulation of discrete adaptations possible; iv) consequently, the theory of evolution by natural selection applies not so much to organisms as to those entities which truly span the ages, the genes (for a corroborative philosophical analysis of Dawkins' position, see Sterelny and Kitcher, 1988; see also Lloyd's 2005 rebuttal).

The gene-centered thesis brings confusion to the units of selection debate as it tends to be presented as a response to Lewontin's question, while in actual fact it responds to a different one. Were it a response to Lewontin's question it would be this: natural selection operates exclusively, or at least primarily, on the genic level of life. As a response to Dawkins' question, it is this: genes are the true beneficiaries of the action of natural selection. As well as the reapparition of Dawkins' aforementioned "adaptationism' (meaning that the essential question for Dawkins is that of adaptive complexity), the main difficulty is that Dawkins doesn't define the problem he claims to answer with sufficient clarity. This ensuing confusion is then carried on by numerous biologists, each one chipping in on the "units of selection" debate, even though it is still not known precisely what question they are actually responding to.

Certain philosophers of biology have played a decisive role in this debate: since the beginning of the 1980s, a handful of them have brought considerable clarification to it (several results of this clarification are detailed in Brandon and Burian, 1984).

One of the most useful clarifications came from David Hull (1980; 1981; 1988, particularly p. 407sq.) Hull proposes the differentiation of two biological entities involved in the evolutionary process: the replicator, being "an entity that passes on its structure directly in replication" (i.e., an entity that is faithfully copied), and the interactor, being "an entity that interacts as a cohesive whole with its environment in such a way that this interaction causes replication to be differential" (i.e., an entity that natural selection acts upon directly) (Hull, 1988 , p. 408). Although some philosophers have recently criticized the idea that all evolutionary processes can be understood through application of the replicator/interactor distinction (Godfrey-Smith, 2009), this distinction has nevertheless quite certainly contributed to clarifying the units of selection debate.

Hull makes it clear that the best replicators, given our current knowledge on the subject, are genes (though this does not mean that they are the only ones; see, for example, Sterelny, 2001) and that therefore the real "units of selection" debate is actually a debate concerning only interactors (Hull, 1992; Lloyd, 1988; Gould, 2002). When the debate is taken at this level, Dawkins' response is not quite so convincing. Admittedly, many biologists find the idea Dawkins popularized to be heuristically useful (e.g., Grafen and Ridley, eds., 2006), but this does not change the fact that the dominant response to Hull's clarified problem (following 
directly on from Lewontin's 1970 suggestions) is that a hierarchy of interactors exists, within which the most clearly defined level is that of the organism, with genes only sometimes having the possibility to be interactors. Indeed, the organism is probably the best example of an interactor since it is upon the organism's phenotypic traits that natural selection primarily operates (e.g., Mayr 1963, 2004; Gould 1980, 2002; Hull, 1988, although the latter is equally insistent that organisms are not the only interactors). Dawkins partially recognized this point in developing his "extended phenotype" conception (Dawkins, 1982). However, for Dawkins the real entity on which natural selection operates is not the organism as such but rather the assembled collection of phenotypic traits upon which genes exercise their influence, that is, the "extended phenotype," something which can go far beyond the boundaries of the organism itself. For example, in the case of a parasite, the nervous system of the host organism can constitute part of the parasite's extended phenotype, as parasitic genes efficient in influencing the nervous systems of their hosts will have been selected by natural selection (Dawkins, 1982, p. 216; for a critical evaluation of the evolution of Dawkins' ideas, see [Hull, 1988] and [Gould, 2002]).

Other philosophers have put forward useful distinctions that at least partially corroborate Hull's. Brandon (1982) expands on Hull and states that the interactors debate should be called the "levels of selection" debate, while the replicators debate be called the "units of selection debate"; Burian proposes a similar distinction (see Brandon and Burian, eds., 1984). Sober (1984: 97-102) distinguishes between selection of (what is conserved after natural selection has happened: referring to effects) and selection for (the reason for which natural selection happened: referring to causes). As for the biologist Niles Eldredge (1984), he proposes distinguishing two classes of living entities, one containing genealogical entities (which pass along information through replication of a structure, typically genes, local populations, and species) and the other containing ecological entities (characterized by stable structure and homeostasis ${ }^{5}$, typically proteins or ecosystems). The biological entity that best occupies both classes, being at once a genealogical and an ecological entity, is the organism.

Using these conceptual clarifications we can in turn provide a historical one. One of the primary sources for confusion in the units of selection debate is the heated discussions around the question of "group selection" and whether it can or cannot occur. But there are several ways to understand this question. Wynne-Edwards (1962) approaches it this way: can groups be the beneficiaries of adaptation? It is this question that Williams (1966), Maynard-Smith (1976), and Dawkins (1976) all answer in the negative, hence their flat-out rejection of group selection. However, if the question of group selection is understood rather as, "Can groups be interactors?" (that is to say, can natural selection occur on the group level?), then the arguments of MaynardSmith, of Williams and of Dawkins become to a large extent ineffective (see, in particular, Wilson and Sober 1989), as all but the latter have come to acknowledge (see Maynard-Smith, 1987, p. 123 and Williams, 1992). So, the confusion between the interactor and the beneficiary questions stems largely from this grand debate in the 1960s and 1970s (on all these points, see Lloyd, 2007). Most surprising in this story is that there is a whole tradition of renowned biologists having openly posed the level of selection question, totally independently of the "beneficiary" of evolution question which they had considered to be irrelevant (Lewontin, 1970; Wright, 1980). Dawkins falls into the prolongation of this interactor/beneficiary confusion and spreads the debate further, into the units of selection domain. He does, however, add a third confusion, between longterm survival and adaptation: for him, cumulative adaptation is so definitely the major phenomenon of evolution that the beneficiary of evolution could only be something which survives over extremely long periods along the evolutionary process. However, no real demonstration for this claim is given. According to Gould (2002), the gene-

\footnotetext{
${ }^{5}$ That is, a system of auto-regulatory processes.
} 
centered view relies on a false comprehension of the theory of evolution by natural selection, and more precisely on a confusion between book-keeping (which refers to the counting of certain hereditary attributes' differential augmentation) and evolution's causality (the mechanism that produces relative reproductive success). Evolutionary causality occurs at the interactor, and not the replicator, level. Furthermore, Dawkins says that to be a unit of selection an entity must possess sufficient stability; this is quite true, but, precisely, organisms do last long enough to act as units of selection in Darwinian processes, thus they do possess the "sufficient stability" required to be counted as evolutionary individuals. Lasting for vast periods of time, up to several millenia, is not a necessary condition for evolution by natural selection. The process of evolution by natural selection does not require perfectly faithful transmission, only the influencing of future generations' biological make up (often genetic). In opposition to genic selectionism, Gould argues for a "hierarchical perspective" on evolution (Gould, 2002; see also Gould and Lloyd, 1999, and Brandon, 1988). According to this perspective, evolution occurs on several levels of natural life (genes, genomes, organelles, cells, organisms, species, etc.), all understood as interactors.

One of the extensions of the hierarchical perspective of evolution is the so-called "multilevel" debate on selection. The following question, in particular, seems pressing: if natural selection operates simultaneously on several levels of life, for example, on an organism and on the cells that make up that organism, wouldn't tensions exist between these levels? (Buss 1987 offers the founding approach to this question). Could it not happen that cell lineages would favor their own fitness at the expense of the organism containing them and its fitness? The example of cancer cells shows that this phenomenon is certainly possible. Work on multi-level selection, mainly inspired by the pioneering work of Buss (1987), has flourished since the 1990s (Maynard-Smith and Szathmary, 1995; Michod, 1999, Okasha, 2006, Godfrey-Smith, 2008 and 2009; etc.) Samir Okasha's book Evolution and the Levels of Selection (Okasha 2004) has played a very useful role in assessing and clarifying the debate, thanks, in particular, to the distinction (suggested by Damuth and Heisler 1988) between "multilevel selection 1" (MLS1, in which a collective's fitness is defined as the average fitness of the particles within the collective) and "multilevel selection 2" (MLS2, in which a collective's fitness is defined as the expected number of offspring collectives contributed to the next generation). One of the results of this work has been to highlight the existence of particular levels in the hierarchy of living things, levels where the competition at lower levels is suppressed, thanks to numerous mechanisms. The best examples of these particular levels could be the multicellular organism (Buss 1987; Michod 1999; Pradeu 2013) and the "superorganism" (Wilson and Sober 1989; Bouchard 2013; Haber 2013) - two notions which, according to some, should be conflated (Queller and Strassmman 2009).

Behind the scenes, so to speak, the units of selection debate also poses a metaphysical question regarding the distinction of biological individuals (Hull 1978, 1980, 1981, 1989a, 1992; Gould, 2002). The criteria generally employed to circumscribe individuals are stability, cohesion, discretion, and continuity. From the theory of evolution by natural selection's point of view, a whole hierarchy of levels of individuality exist (gene, cell, organism, species, etc.) Species, for example, are "individuals" in that they are spatio-temporally defined entities, and not classes of individuals. This means that a species is defined genealogically and not by some intrinsic properties which would be common to all its members (Ghiselin, 1974; Hull, 1976, 1978). Nevertheless, the biological entity that best satisfies all the criteria for being a biological individual in the sense of an interactor is probably the organism (Eldredge, 1984; Hull, 1978; Gould, 2002), an observation which, coming in the wake of numerous criticisms leveled at the privileging of the organism biological level (particularly following Dawkins' remarks, 1976), could now lead the organism back to its central position. In addition, it is likely that the articulation of evolutionary and physiological (in particular immunological) criteria of 
individuality will strengthen the view of organisms as highly individuated entities (Pradeu 2010b, 2012).

Recently, Peter Godfrey-Smith (2009) has offered a different picture of biological individuality. Godfrey-Smith defines "Darwinian individuals" as members of a "Darwinian population," which itself is defined as a population of entities characterized by variation, heredity and differential fitness. On this basis, Godfrey-Smith suggests to distinguish several components of Darwinian individuality, and several degrees of this individuality, which has led him to propose a renewed conception of biological individuality (Godfrey-Smith 2013).

Frédéric Bouchard has suggested a very different view, according to which one must not give too much weight to the process of reproduction in the Darwinian theory of evolution, and one should instead focus on the process of persistence (of which reproduction would just be an instantiation). Fitness, Bouchard suggests, is often more a question of determining which entities live longer than others than which entities reproduce more than others. Therefore, Bouchard proposes a re-definition of fitness on the basis of this idea of differential persistence of lineages (Bouchard 2010).

As all these discussions make clear, the debate over levels of selection and biological individuality is far from closed in biology and philosophy of biology. It will certainly continue to foster fruitful discussions in the near future.

\section{From egg to adult, from egg to death: development in organisms}

Development is the construction of a novel organismal form. Development is commonly, but not indisputably, thought as the set of processes which accompany life from the egg stage to sexual maturity. Although development did not get a lot of attention from the first philosophers of biology, it has today become the subject of intense research (e.g., Oyama 2000[1985]; Amundson 1994; Gilbert and Raunio 1997; Griesemer 2000; Oyama, Griffiths and Gray 2001; Brigandt 2002; Burian 2005; Laubichler, 2007; Laubichler \& Maienschein, 2007; Love 2008; Pradeu et al. 2011; Minelli and Pradeu 2014).

An important problem is the connection of development and the notion of information, which plays a crucial role in molecular biology. Generally it is said that genes bear information, in that they "encode" for the synthesis of precise proteins, according to some maybe even for the expression of phenotypic traits (Monod 1971; Jacob, 1973; see also Sarkar, 2004 and Maynard-Smith, 2000), a point of view which has been analyzed critically by several philosophers (especially see Sarkar, 1996; Oyama, 2000; Godfrey-Smith, 2004; Godfrey-Smith and Sterelny, 2007). In developmental biology, the debate has become focused around the question of whether or not genes contain all the information necessary for the formation of an embryo and the adult organism, even whether this formation is not "programmed" by the genes, as many biologists had claimed between the 1970s and 1990s (amongst the most influential see Mayr 1969a; Monod 1971; Jacob, 1973; Monod, 1970; Gilbert, 1992; Wolpert 1994) and as certain philosophers of biology believe today (Rosenberg, 1997, 2007). According to the genetic program hypothesis, genes contain all the information which, once "read," enables the realization of a complete individual organism. The difficulty lies in the fact that nothing allows us to isolate any particular meaning for the term "information" that would make it specifically applicable to genes but not to other developmental factors (epigenetic, environmental, etc.), as the partisans of "developmental systems theory" (DST) have shown (Oyama, 2000; Griffiths \& Gray, 1994; Griffiths, 2001; Oyama, Griffiths and Gray 2001; Griffiths and Stotz 2013). Certain philosophers (Oyama, 2000; Oyama, 2009; Francis, 2003) even advance excellent arguments for considering that the very notion of information carries too much risk (notably the risk of anthropomorphism) to be allowed a place in biology.

The work of clarification on the notion of information in developmental systems theory has been accompanied by questioning into the temporal and spatial boundaries of development 
(Pradeu et al. 2011). From a temporal point of view it seems preferable to say that development doesn't simply stop at adulthood but that in reality it continues throughout life as a continuous constructive interaction with the environment (Gilbert 2013). From a spatial point of view DST, following on from Lewontin (1983), rejects the theory that the organism is simply a product of the self-actualization of internal potentialities (an idea which is really just a contemporary form of preformationism: see Lewontin 2000), and asserts that it comes into being through incessant interaction with its environment. This is where the idea that what actually develops is the system made up of the organism and its environment comes from (Oyama, 2000; Oyama, Griffiths and Gray 2001; Griffiths and Gray, 2004). This insistence on the interactions between the developing organism and its environment aligns with Scott Gilbert's so-called "eco-evo-devo" perspective (connecting ecology, evolution and development) (Gilbert, 2001, 2002, 2006; Gilbert and Epel 2009) and its meeting point with niche construction (Laland, Odling-Smee and Gilbert, 2008)

Important, yet to be examined in detail, questions about development include the causality of development, the formulation of general "principles" of embryogenesis, and the exact role played by theories in developmental biology (see Minelli and Pradeu 2014).

Regarding developmental biology's place within the life sciences, something previously unnoticed became evident in the 1980s: developmental biology had, to a great extent, been neglected during the Modern Synthesis of the 1920s to 1950s (Hamburger, 1980). "Evo-devo" is the name given to the domain dedicated to connecting developmental biology with biology of evolution. The evo-devo field, thus called, is a recent one. Its sources are generally considered to be a few articles and publications from the 1980s and 1990s (particularly, Raff \& Raff, eds., 1987; Hall, 1992; Raff, 1996; Gilbert, Opitz \& Raff, 1996); its institutionalization in research programs and journals (Evolution and Development; Journal of Experimental Biology Part B) primarily took place on the cusp of the 1990s to 2000s. However, attempts to bring together results from biology of evolution and embryology, now known as developmental biology, have a long history, particularly in the $20^{\text {th }}$ century (especially Waddington, 1940; Gould, 1977), but going further back also (see Gilbert, Opitz and Raff 1996; Minelli 2003; Amundson 2005; Laubichler and Maienschein, 2007). 2007):

The principal problems posed in evo-devo are as follows (Laubichler, 2007; Müller,

1) The origin and the evolution of developing systems. Even though development seems to be both stable and robust over time, in fact developmental mechanisms change with evolution. It is these changes that are studied in the scope of this first problem. The notions of module and correlatively of modularity ${ }^{6}$ have acquired decisive importance in this research (for an overview, see Müller, 2007).

2) The homology problem. How does one determine what counts as a homology and explain the emergence of homologies in the course of evolution (Brigandt 2002; Griffiths, 2006; Griffiths, 2007)?

3) The relationship between genotype and phenotype. The claim, long held in population genetics, that development does not influence the correspondence between genotype and phenotype (the idea that development could be seen as a sort of "black box") can no longer be

\footnotetext{
${ }^{6}$ A module is a sub-system within the developing system (the latter may be an organism, a cell, etc.), characterized by intense interactions between its constituent parts, relative independence with respect to the system as a whole, an auto-regulatory capacity, redundancy (the same effect can be obtained in various ways) and persistence throughout evolution (some modules are found, sometimes in differing forms, in various species, some of which are in no way closely related). The module is to be found at an intermediary level, between easily individuated entities (such as cells in the case of an organism) and the level of the system in its totality (for example, the organism itself). An oft described example of a module is gene networks, with their regulatory systems. See for example von Dassow \& Munro (1999).
} 
accepted today. Research into phenotypic plasticity (West-Eberhard, 2003) is one way of posing the genotype-phenotype relationship problem anew.

4) Developmental constraints on phenotypic variations (Maynard-Smith et al. 1985; Amundson 1994). The problem here is determining in what way development limits and constrains the range of possibles for phenotypic variations.

5) The role of the environment in development and evolution. This role, long looked over, is considered to be absolutely crucial today (Gilbert and Epel 2009; the role of symbiosis in development seems especially important: McFall-Ngai 2002; Pradeu 2011; McFall-Ngai et al. 2013).

6) The origin of evolutionary innovations. With genes (particularly regulatory genes like Hox) being highly persistent through evolution, it is necessary to look to other explanatory factors than just genes for an explanation of the manifest phenotypic differences between the species. Many consider that the explanation resides in the developmental modifications of gene regulation networks, but it still remains difficult to define with any precision what is to count as an "evolutionary innovation" (Müller and Wagner, 1991; Müller, 2007). Several developmental biologists claim that the theory of evolution resulting from the Modern Synthesis does not offer an explanation for evolutionary innovation and that this explanation must rather be provided by developmental biology, in opposition to the "classical" view (Gilbert, Opitz and Raff 1996; Gilbert, 2006).

There is almost full consensus in affirming that the years to come will see evo-devo becoming one of the most dynamic fields within biology and one of the most exciting for philosophy of biology (Hull, 2002; Amundson, 2005; Laubichler, 2007). It is nevertheless not easy to tell whether or not this field will profoundly modify the acquired knowledge of the Modern Synthesis as its followers regularly and insistently claim it will. Most likely, evo-devo will neither replace nor erase the Modern Synthesis, but rather complete it, and decisively so (Arthur, 2002; Hull, 2002; Amundson, 2005; Minelli, 2010).

\section{Reductionism and the gene concept}

Though it may have enthralled the first philosophers of biology, as a result of logical positivism's influence, the problem of biology's reduction to physical chemistry seems now to belong to the past. There is full consensus regarding physicalism (ontological reductionism), which states that all biological processes are nothing other than physicochemical. There is also almost full consensus regarding explanatory anti-reductionism, i.e. the assertion that we cannot adequately explain biological processes by means of physicochemical theories and terms. These questions recently resurfaced during debates on the notion of emergence ${ }^{7}$ applied to biology (see for example, Wimsatt, 2007, and, for a general overview, Bedau and Humphreys, 2008; on the related notions of self-organization and complexity, see Kauffman, 1993) but not in a way that challenged this double consensus.

The real issue now concerns the possibility of an internal explanatory (theoretical) reductionism in biology, and more precisely the possibility of reducing macromolecular biology to molecular biology (e.g., Rosenberg, 2007). According to the reductionists, all biological explanations must be completed, amended, clarified by more fundamental explanations coming from molecular biology. Discussion on this reductionism has been focused on the possibility of reducing Mendelian genetics to molecular genetics. The word gene, originating from the term pangene, has a very loose meaning within Mendelian genetics: it refers simply to a factor of

\footnotetext{
7 To simply, let us simply say that a property is said to be "emergent" relative to a system (an organism, for example) if it is not reducible to the properties possessed by the constituent parts of that system (for example, the organism's cells). On the distinction between ontological and epistemological emergence, see, for example, Wimsatt (2007).
} 
heredity. Mendelian genetics is a theory of hybridization and transmission; it is interested in genetic differences, which are correlated to the possession of this or that trait. Following the discoveries made by molecular biology in the $20^{\text {th }}$ century, in particular the discovery of the double helix structure of DNA in 1953, the question arose as to whether it would be possible to reduce Mendelian genetics to molecular genetics. In molecular genetics, which is a theory of development and not a theory of heredity, the gene is an encoding sequence of nucleotides for the synthesis of a protein (Hull, 1974). The question of reducing Mendelian genetics to molecular genetics attracted practically all of the first philosophers of biology. There is a relative consensus to responding to this question in the negative because genetic processes are just far too complex to envisage identifying a Mendelian gene with some particular continuous sequence of nucleotides (see for example Hull, 1974; Kitcher, 1984; Mayr, 2004. See also, however, Schaffner, 1967; Ruse, 1971; Rosenberg, 1984, 2007; Waters, 1990).

One of the most beneficial consequences of this debate has been the testing of the term "gene" itself. Indeed, it turned out that, contrary to popular belief, it was extremely difficult to precisely answer the question "What is a gene?" (Falk, 2000; Keller 2000). Griffiths and Stotz (2007, 2013) distinguish three definitions for gene: the instrumental gene (a "Mendelian factor", i.e. a variable which takes part in the Mendelian transmission of a phenotypic trait), the nominal gene (referencing the nucleotide sequences similar to those which were studied at the time of molecular biology's discoveries in the 1950s to 1970s, such as sonic hedgehog), and the classical molecular gene (a sequence of nucleotides which determines the structure of biological products, typically proteins) which has today become the post-genomic gene (the complex set of elements carrying out the function believed to have been carried out by the molecular gene). All three of these definitions are useful, but their coexistence suggests that it has become indispensable, for biologists speaking about genes, to specify which signification they are intending.

To conclude on this point, is it possible to reduce macromolecular biology to molecular biology? If the disciples of this reduction continue to put the emphasis on the idea that it is necessary to complete macromolecular explanations with molecular explanations (constituting a weak form of "reduction"), as Rosenberg (2007) seems to be doing more and more, then, given the ever more repeated affirmation of a need to connect various modes of explanation within contemporary biology (Lewontin, 2009; Morange, 2009), we may consider that a consensus on this matter is beginning to emerge.

\section{Philosophy of biology beyond evolution}

As was noted at the beginning of this chapter, the field of philosophy of biology is dominated by evolutionary issues. A significant illustration of this fact is that, from 2008 to $2012,64 \%$ of the articles published in the journal Biology and Philosophy concerned evolution (Pradeu 2017). This focus on evolution is easy to understand, as evolution raises fundamental philosophical questions about the nature of species, the status of human beings in the living world, essentialism, individuality, etc.

But this almost exclusive attention paid to evolutionary biology in philosophy of biology could also become problematic. Philosophers of biology have always aimed at working in close connection with biologists and at reflecting on the "real" and current biological sciences. The difficulty is that the great majority of the articles currently published in biology are not about evolution (though, of course, they accept the theory of evolution as an essential background). In the same period (2008-2012) during which Biology and Philosophy published 64\% about evolution, the Proceedings of the National Academy of the Sciences of the USA (PNAS), one of the major scientific journals in the world, had $6 \%$ of its biological papers put in the "evolution" section. The most exciting and discussed breakthroughs in today's biology concern fields such as neurobiology, cancerology, immunology, microbiology (and especially virology), 
or the renewed "omics" studies in molecular biology (genomics, proteomics, metabolomics) all fields that have been almost entirely neglected by philosophers of biology.

Yet the situation has started to change. A growing number of philosophers of biology have become interested in neurobiology (e.g., Craver 2007), microbiology (e.g., O'Malley and Dupré 2007; Dupré and O’Malley 2009; O’Malley 2013), immunology (Tauber 1994; Pradeu 2012), or in the "omics" detailed of recent molecular biology (e.g., Griffiths and Stotz 2013). If philosophers of biology want to maintain their wish to remain closely connected to biology as it is actually done today, it is likely that the young generations in the field will be increasingly attracted by these domains and the often highly philosophical questions that they raise.

\section{Conclusion}

I have presented in this chapter some of the major problems raised by today's philosophy of biology. Due to space limitation, many important issues and domains have not been analyzed, including the evolution of humans, the human $\operatorname{mind}^{8}$ and the possibility to speak of a "human nature." 9 To conclude, I would like to come back to the problem with which we started this chapter, namely the ties that exist between philosophy of biology and general philosophy of science.

In 1969 two seminal articles appeared, one by a philosopher (Hull, 1969), the other by a biologist (Mayr, 1969b). The first mourned the fact that a philosophy both specific to biology and well instructed on biological findings had not yet emerged; the second affirmed that "philosophy of science" more fittingly suited the moniker "philosophy of physics", and called for a rejuvenation of philosophy of science through the embracing of the magnificent advances accomplished in the life sciences. Almost fifty years on, the status report, as I see it, is this: Hull's wishes have been answered, better than he could have hoped, while Mayr's are still far from fruition.

Philosophy of biology, in accordance with Hull's wish, has today become a well structured and flourishing philosophical domain with its own journals, academic circle, etc. It can even be viewed as a genuine example for all philosophies of science (in saying this, we certainly don't mean the only example) in at least two respects. Firstly, it has enabled real progress to be made, as much from the philosophical as the scientific point of view. Secondly, it is characterized by genuine collaboration and dialog with scientists, the best example of which is that the journal Biology and Philosophy not only hosts frequent contributions from biologists but is also regularly cited in scientific journals. Several biologists have made major contributions to philosophy of biology (Dawkins, Gould, Lewontin, Maynard-Smith, Mayr, in particular). Philosophers of biology have played, and continue to play, an important role in biology, something that is quite exceptional in philosophy of science. ${ }^{10}$ Several biologists have openly acknowledged this, like Gould, for example, when he affirmed that philosophers have brought remarkable clarification to the biological debate on units of selection (Gould 2002: 598). From this point of view, we can highlight the contrast between Hull's original discourse (1969, p. 259), where he says that philosophers had not yet contributed to biology but that they could and should do so, and what he shows in (Hull, 2002), which is the fact that this contribution has become a reality.

\footnotetext{
${ }^{8}$ These issues, often situated at the frontier between philosophy of cognitive science, psychology and philosophy of biology, are well-represented in a journal like Biology and Philosophy. For a very stimulating example of a recent work situated at this frontier, see Sterelny (2012).

9 These issues are at the crossroads between philosophy of biology and ethics. See for example Wilson (1975, 1978), Hull (1986), Francis (2003), and Ayala (2009).

${ }^{10}$ Physicist Richard Feynman supposedly said that, in his view, philosophy of science was no more useful to science than ornithology is to birds. Philosophy of biology clearly demonstrates that he was mistaken.
} 
However, in parallel, philosophy of biology has established a quite strong autonomy with respect to general philosophy of science, with less and less importance being given over to the latter's fundamental problems, often considered to be too dependent on its particular conditions of development (logical positivism, the physics model, etc.), and more and more attention being given to the grand problems of general philosophy (What is an individual? What are the entities that make up the world? Where is the frontier between man and animal? Can we explain the origins of morality? Are humans free or determined? Can we speak of such a thing as "human nature"?). And so, philosophy of biology, unquestionably a well structured domain posing classical philosophical problems, has not yet sufficiently lead to a rejuvenation of general philosophy of science, and thus seems to have failed in assuaging Mayr's (1969b) regrets for the discipline.

How and ever, there are many signs indicating that a new phase is now taking shape, a phase where, precisely, general philosophy of science undergoes a partial re-creation thanks to the contribution of philosophy of biology (see for example Hull, 1988; Craver 2005; GodfreySmith, 2006; Wimsatt, 2007; Sober, 2008; Stotz \& Griffiths, 2008; Woodward, 2010). We can but impatiently await the fruit of this rejuvenation.

\section{References}

Allen, G. E. (1969). Hugo de Vries and the reception of the "mutation theory". Journal of the History of Biology, 2(1), 55-87.

Amundson, R. (1994). Two concepts of constraint: Adaptationism and the challenge from developmental biology. Philosophy of Science 61(4), 556-578.

Amundson, R., 2005, The Changing Role of the Embryo in Evolutionary Thought, Cambridge, Cambridge University Press.

Arthur, W., 2002, "The emergent conceptual framework of evolutionary developmental biology", Nature, 415, p. 757-764.

Ayala, F., 2009, "What the Biological Sciences Can and Cannot Contribute to Ethics", in Ayala, F. \& Arp, R. (eds.).

Ayala, F. \& Arp, R. (eds.), 2009, Contemporary Debates in Philosophy of Biology, Oxford, Wiley-Blackwell.

Barberousse, A., Morange, M. \& Pradeu, T. (2009), Mapping the Future of Biology. Evolving Concepts and Theories, Boston Studies in the Philosophy and History of Science, 266, Dordrecht, Springer.

Beatty, J. 1995, The evolutionary contingency thesis. In G. Wolters and J.G. Lennox, eds. Concepts, Theories, and Rationality in the Biological Sciences, pp. 45-81. Universitätsverlag Konstanz, Konstanz, University of Pittsburgh Press, Pittsburgh.

Bechtel, W., 2005, Discovering Cell Mechanisms, Cambridge, Cambridge University Press.

Bedau, M. \& Humphreys, P., 2008, Emergence: Contemporary Readings in Philosophy and Science, Cambridge, MA, MIT Press.

Bouchard, F., 2008, Causal processes, fitness, and the differential persistence of lineages. Philosophy of Science, 75(5), 560-570.

Bouchard, F., 2013, What Is a Symbiotic Superindividual and How Do You Measure Its Fitness? In F. Bouchard and P. Huneman (eds.) From Groups to Individuals: Perspectives on Biological Associations and Emerging Individuality. Cambridge, MA: MIT Press, 243-264.

Brandon, R., 1978, "Adaptation and Evolutionary Theory", Studies in the History and Philosophy of Science, 9, p. 181-206.

Brandon, R., 1988, "The Levels of Selection: A Hierarchy of Interactors", in H. Plotkin, ed., The Role of Behavior in Evolution, Cambridge, MA, MIT Press, p. 51-71.

Brandon, R., 1990, Adaptation and environment, Cambridge, Cambridge University Press. 
Brandon, R. \& Burian, R. (eds), 1984, Genes, Organisms and Populations. Controversies Over the Units of Selection, Cambridge, MA, MIT Press.

Brigandt, I. (2002). Homology and the origin of correspondence. Biology and Philosophy, 17(3), 389-407.

Burian, R., 1983, "Adaptation", in M. Greene, ed., Dimensions of Darwinism, New York \& Cambridge, Cambridge University Press, p. 287-314.

Burian, R., 2005, The Epistemology of Development, Evolution, and Genetics. Cambridge, Cambridge University Press.

Buss, L., 1987, The Evolution of individuality, Princeton, Princeton University Press.

Byron, J. M., 2007, "Whence Philosophy of Biology?", British Journal for the Philosophy of Science, 58(3), p. 409-422.

Craver, C., 2005, "Beyond Reduction: Mechanisms, Multifield Integration, and the Unity of Science," Studies in History and Philosophy of Biological and Biomedical Sciences 36:373396.

Craver, C., 2007, Explaining the Brain: Mechanisms and the Mosaic Unity of Neuroscience, Oxford, Oxford University Press.

Cummins, R., 1975, "Functional Analysis", The Journal of Philosophy, 72, p. 741-764. Reprinted in Sober, E., ed., 1994.

Damuth, J. and Heisler, I.L., 1988, “Alternative formulations of multi-level selection”, Biology and Philosophy, 3, 407-430.

Darwin, C., 1859, The Origin of the Species. London, John Murray.

Darwin, C., 1880, "Sir Wyville Thomson and Natural Selection", Nature, $23,32$.

Dassow (von), G. \& Munro, E., 1999, "Modularity in Animal Development and Evolution: Elements of a Conceptual Framework for EvoDevo", Journal of Experimental Zoology B (Mol Dev Evol), 285, p. 307-325.

Dawkins, R., 1976, The Selfish Gene, Oxford, Oxford University Press.

Dawkins, R., 1982, The Extended Phenotype, Oxford, Oxford University Press.

Dawkins, R., 1986, The Blind Watchmaker, New York, Norton.

Dennett, D., 1995, Darwin's Dangerous Idea, New York, Simon and Schuster.

Dupré, J. 1987, The Latest on the Best: Essays on Evolution and Optimality. Cambridge, MA: MIT Press.

Dupré, J., and O'Malley, M., 2009, "Varieties of living things: Life at the intersection of lineages and metabolism." Philosophy and Theory in Biology 1.

Eldredge, N., 1984, "Large-scale biological entities and the evolutionary process", Proceedings of the Biennial Meeting of the Philosophy of Science Association 1984, vol. 2, p. 551-566.

Ereshefsky, M., 1991, The Semantic Approach to Evolutionary Theory. Biology and Philosophy 6, 59-80.

Falk, R., 2000, "The gene: A concept in tension", in Beurton, P., Falk, R. \& Rheinberger, H-J. (eds.), The Concept of the Gene in Development and Evolution. Historical and Epistemological Perspectives, Cambridge, Cambridge University Press, p. 317-348.

Fisher, R.A., 1930, The Genetical Theory of Natural Selection, Oxford, Clarendon Press.

Francis, R., 2003, Why Men Won't Ask for Directions: The Seductions of Sociobiology, Princeton, Princeton University Press.

Gayon, J., 1993, "La biologie entre loi et histoire", Philosophie, 38, p. 30-57.

Gayon, J., 1998, Darwinism's Struggle for Survival: Heredity and the Hypothesis of Natural Selection, Cambridge, Cambridge University Press.

Gayon, J., 2006, "Les biologistes ont-ils besoin du concept de fonction? Perspective philosophique", Comptes Rendus Palevol., 5, p. 479-487.

Ghiselin, M., 1969, The Triumph of the Darwinian Method, Dover. 
Ghiselin, M., 1974, "A Radical Solution to the Species Problem", Systematic Zoology, 23, p. 536-44.

Ghiselin, M., 1983, "Lloyd Morgan's Canon in Evolutionary Context", Behavioral and Brain Sciences, 6, p. 362-363.

Gilbert, S.F., 2001, "Ecological developmental biology: developmental biology meets the real world", Developmental Biology, 233, p. 1-12.

Gilbert, S.F., 2002, "The genome in its ecological context", Annals of the New York Academy of Science, 981, p. 202-218.

Gilbert, S.F., 2006, "The Generation of Novelty: The Province of Developmental Biology", Biological Theory, 1(2), p. 209-212.

Gilbert, S.F. (2013). Developmental Biology, $10^{\text {th }}$ ed. Sinauer Associates, Sunderland, MA.

Gilbert, S.F. and Epel, D., 2009, Ecological Developmental Biology, Sunderland, MA, Sinauer Associates, Inc. Publishers.

Gilbert, S.F., Opitz, J.M. \& Raff, R. A., 1996, "Resynthesizing Evolutionary and Developmental Biology", Developmental Biology, 173, p. 357-372.

Gilbert, S.F. and Raunio, A.M. (1997), eds., Embryology: Constructing the Organism. Sinauer Associates, Sunderland, MA.

Gilbert, W., 1992, "Vision of the grail", in D. J. Kevles and L. Hood (eds.) The Code of Codes, Cambridge, MA, Harvard University Press, p. 83-97.

Godfrey-Smith, P., 1993, "Functions: Consensus without unity", Pacific Philosophical Quarterly, 74, p. 196-208. Reprinted in Hull, D. \& Ruse, M., eds., 1998, p. 280-292.

Godfrey-Smith, P., 2000, "The Replicator in Retrospect", Biology and Philosophy, 15, p. 403423.

Godfrey-Smith, P., 2001, "Three kinds of adaptationism", in Orzack, S. \& Sober, E., eds., 2001, Adaptationism and Optimality, Cambridge, Cambridge University Press.

Godfrey-Smith, P., 2004, "Genes do not Encode Information for Phenotypic Traits", in Hitchcock, C., ed., Contemporary Debates in Philosophy of Science, Malden, Blackwell, p. 275-289.

Godfrey-Smith, P., 2006, "The strategy of model-based science", Biology and Philosophy, 21, p. $725-740$.

Godfrey-Smith, P., 2007, "Conditions for evolution by natural selection", The Journal of Philosophy, 104, p. 489-516.

Godfrey-Smith, P., 2008, "Varieties of Population Structure and the Levels of Selection", British Journal for the Philosophy of Science, 59, p. 25-50.

Godfrey-Smith, P., 2009, Darwinian Populations and Natural Selection, Oxford, Oxford University Press.

Godfrey-Smith, P. 2014. Philosophy of Biology. Princeton: Princeton University Press.

Godfrey-Smith, P. and Sterelny, K., 2007, "Biological Information", Stanford Encyclopedia of Philosophy (online).

Gould, S. J., 1977, Ontogeny and Phylogeny, Cambridge, MA, Belknap Press.

Gould, S. J., 1980, The Panda's Thumb, New York, Norton.

Gould, S. J., 2002, The Structure of Evolutionary Theory, Cambridge, MA, Harvard University Press.

Gould, S. J. \& Lewontin, R., 1979, "The Spandrels of San Marco and the Panglossian Paradigm: A Critique of the Adaptationist Programme", Proceedings of the Royal Society of London B 205, p. 581-98. Reprinted in Sober, E., ed., 2006.

Gould, S. J. \& Lloyd, E., 1999, "Individuality and adaptation across levels of selection: How shall we name and generalize the unit of Darwinism?", PNAS USA 96(21), p. 11904-11909.

Grafen, A. \& Ridley, M. (eds.), 2006, Richard Dawkins: how a scientist changed the way we think, Oxford, Oxford University Press. 
Griesemer, J. (2000). Development, culture and the units of inheritance. Philosophy of Science, 67 (Proceedings), S348-S368.

Griffiths, P., 2001, "Genetic Information: A Metaphor In Search of a Theory", Philosophy of Science, 68(3), p. 394-412.

Griffiths, P., 2006, "Function, Homology and Character Individuation", Philosophy of Science, 73(1), p. 1-25.

Griffiths, P., 2007, "The Phenomena of Homology", Biology and Philosophy, 22(5), p. 643658.

Griffiths, P. \& Gray, R., 1994, "Developmental Systems and Evolutionary Explanation", Journal of Philosophy, 91, p. 277-304. Reprinted in Hull, D. \& Ruse, M. (eds.), 1998.

Griffiths, P. \& Gray, R., 2004, "The Developmental Systems Perspective: Organismenvironment systems as units of development and evolution", in Pigliucci, M. \& Preston, K. (eds.), Phenotypic Integration: Studying the Ecology and Evolution of Complex Phenotypes, Oxford \& New York, Oxford University Press, p. 409-430.

Griffiths, P. \& Stotz, K., 2007, "Gene", in Hull, D. \& Ruse, M. (eds.)

Griffiths, P. \& Stotz, K., 2013, Genetics and Philosophy: An Introduction. Cambridge: Cambridge University Press.

Haber, M., 2013, Colonies are individuals: revisiting the superorganism revival. In F. Bouchard and P. Huneman (eds.) From Groups to Individuals: Perspectives on Biological Associations and Emerging Individuality. Cambridge, MA: MIT Press, 195-217.

Hall, B. K., 1992, Evolutionary Developmental Biology, New York, Chapman and Hall.

Hamburger, V., 1980, "Embryology and the Modern Synthesis in Evolutionary Theory", in Mayr, E. \& Provine, W. B, eds., p. 97-112.

Hempel, C. G. (1965), Aspects of Scientific Explanation, New York, The Free Press.

Hull, D., 1969, "What philosophy of biology is not", Journal of the History of Biology, 2(1), p. 241-268.

Hull, D., 1974, Philosophy of Biological Science, Englewood Cliffs, N.J., Prentice-Hall.

Hull, D., 1976, "Are Species Really Individuals?", Systematic Zoology, 25, p. 174-191.

Hull, D., 1977, "A Logical Empiricist Looks at Biology", The British Journal for the Philosophy of Science, 28(2), p. 181-189.

Hull, D., 1978, "A Matter of Individuality", Philosophy of Science, 45, p. 335-60. Reprinted in Sober, E., ed. 2006, p. 363-386.

Hull, D., 1980, "Individuality and Selection", Annual Review of Ecology and Systematics, 11, p. 11-332.

Hull, D., 1981, "Units of Evolution: A Metaphysical Essay", in Jensen, U.J. \& Harré, R. eds., The Philosophy of Evolution, Brighton, England, The Harvester Press, p. 23-44. Reprinted in Brandon, R.N. \& Burian, R.M., eds., 1984, p. 142-160.

Hull, D., 1986, "On Human Nature", Proceedings of the Philosophy of Science Association, ii, p. 3-13. Reprinted in Hull, D. \& Ruse, M., eds., 1998, p. 383-397.

Hull, D., 1988, Science as a Process: An Evolutionary Account of the Social and Conceptual Development of Science, Chicago, Chicago University Press.

Hull, D., 1989a, The Metaphysics of Evolution, Albany, State University of New York Press. Hull, D., 1989b, "A Function for Actual Examples in Philosophy of Science", in Ruse, M. (ed.) What the Philosophy of Biology Is: Essays dedicated to David Hull, Dordrecht, Holland, Kluwer Academic Publishing, p. 313-324. Reprinted in Hull, D., Science and Selection: Essays on Biological Evolution and the Philosophy of Science, Cambridge, Cambridge University Press, 2001.

Hull, D., 2002, "Recent philosophy of biology: A review", Acta Biotheoretica, 50, 117-128.

Hull, D. \& Ruse, M., eds., 1998, The Philosophy of Biology, Oxford, Oxford University Press. 
Hull, D. \& Ruse, M., eds., 2007, The Cambridge Companion to the Philosophy of Biology, Cambridge, Cambridge University Press.

Jablonka, E., and Lamb, M. J., 2005. Evolution in four dimensions: Genetic, epigenetic, behavioral, and symbolic variation in the history of life. Cambridge, MA: MIT press.

Jacob, F., 1973 [1970], The Logic of Life: A History of Heredity. Translated by Betty E. Spillmann. New York : Pantheon Books.

Kauffman, S., 1993, The Origins of Order: Self-Organization and Selection in Evolution, Oxford, Oxford University Press.

Kimura, M., 1983, The Neutral Theory of Molecular Evolution, Cambridge, Cambridge University Press.

Kitcher, P. S., "1953 and all That. A Tale of Two Sciences", Philosophy of Science, 93(3), p. 335-373.

Kitcher, P. S., 1993, "Function and Design", Midwest Studies in Philosophy, 18(1), p. 379-397. Reprinted in Ruse, M. \& Hull, D., eds., 1998, p. 258-279.

Laland, K., Odling-Smee, J. \& Gilbert, S. F., 2008, "EvoDevo and Niche Construction: Building Bridges", Journal of Experimental Zoology (Mol Dev Evol), 310(B), p. 1-18.

Laubichler, M., 2007, "Evolutionary Developmental Biology", in Hull, D. \& Ruse, M. (eds.), p. 342-360.

Laubichler, M. \& Maienschein, J., 2007, From Embryology to Evo-Devo, Cambridge, MA, MIT Press.

Levins, R. \& Lewontin, R., 1985, The Dialectical Biologist, Cambridge, MA, Harvard University Press.

Lewens, T., 2007a, Darwin, London \& New York, Rouledge.

Lewens, T., 2007b, "Adaptation", in D. Hull and M. Ruse (eds.), p. 1-21.

Lewens, T., 2009, "Seven kinds of adaptationism", Biology and Philosophy 24(2), p. 161-182.

Lewontin, R., 1970, "Units of selection", Annual Review of Ecology and Systematics, 1, p. 118.

Lewontin, R., 1978, "Adaptation", Scientific American, 239(9), p. 156-169. Reprinted in a slightly different version in Levins, R. \& Lewontin, R., 1985, p. 65-84.

Lewontin, R., 1983, "The Organism as the Subject and Object of Evolution", Scientia, 118, p. 63-82. Repris in Levins, R. \& Lewontin, R., The Dialectical Biologist, 1985, p. 86-106.

Lewontin, R., 1985, "Adaptation", in R. Levins and R. Lewontin, The Dialectical Biologist. Cambridge, MA, Harvard University Press, 65-84.

Lewontin, R., 2000, The Triple Helix, Cambridge, MA, Harvard University Press.

Lewontin, R., 2009, "Carving Nature at its Joints", in Barberousse, A., Morange, M. \& Pradeu, T. (eds.)

Lloyd, E., 1993, The Structure and Confirmation of Evolutionary Theory, Princeton University Press, $1^{\text {ère }}$ éd. 1988.

Lloyd, E., 2005, "Why the Gene will not return", Philosophy of Science, 72, p. 287-310.

Lloyd, E., 2007, "Units and Levels of Selection", in Hull, D. \& Ruse, M. (eds.), p. 44-65.

Machamer, P., Darden, L., Craver, C., 2000, "Thinking about mechanisms", Philosophy of Science, 67(1), p. 1-25.

Maynard-Smith, J., 1969, "The status of neo-Darwinism", in Waddington, C. H., ed. Towards a Theoretical Biology, Edinburgh, Edinburgh University Press.

Maynard-Smith, J., 1976, "Group Selection", Quarterly Review of Biology, 51, p. 277-283.

Maynard-Smith, J., 1987, "How to model evolution", in Dupré, J., ed., The Latest on the Best: Essays on Evolution and Optimality, Cambridge, MA, MIT Press, p. 119-131.

Maynard Smith, J., 2000, "The Concept of Information in Biology", Philosophy of Science, 67, p. 177-194. 
Maynard-Smith, J., Burian, R., Kauffman, S., et al. (1985). Developmental constraints and evolution. Quarterly Review of Biology 60(3), 265-287.

Maynard-Smith, J. and Szathmary, E., 1995, The Major Transitions in Evolution, Oxford \& New York, W. H. Freeman Spektrum.

Mayr, E., 1961, "Cause and effect in biology", Science, 134, p. 1501-1506.

Mayr, E., 1963, Animal Species and Evolution, Cambridge, MA, Harvard University Press.

Mayr, E., 1969a, Comments on 'Theories and hypotheses in biology'. In R.S. Cohen and M.W. Wartofsky, eds. Boston Studies in the Philosophy of Science, Vol. 5, pp. 452-456. Springer, Dordrecht. Reprinted under the title "Theory formation in developmental biology", in E. Mayr (1976) Evolution and the Diversity of Life. Selected Essays, pp. 377-382. Harvard University Press, Cambridge, MA.

Mayr, E., 1969b, Footnotes on the philosophy of biology. Philosophy of Science, 36, 197-202. Mayr, E., 1982, The Growth of biological thought, Cambridge, MA, Harvard University Press. Mayr, E., 2004, What Makes Biology Unique, Cambridge, Cambridge University Press.

Mayr, E. \& Provine, W. B., eds., 1980, The Evolutionary Synthesis, Cambridge, MA, Harvard University Press.

McFall-Ngai, M. J. (2002). Unseen forces: the influence of bacteria on animal development. Developmental Biology, 242(1), 1-14.

McFall-Ngai, M. et al. (2013). Animals in a bacterial world, a new imperative for the life sciences. Proceedings of the National Academy of Sciences, 110(9), 3229-3236.

Michod, R., 1999, Darwinian Dynamics : Evolutionary Transitions in Fitness and Individuality, Princeton, NJ, Princeton University Press.

Mills, S. \& Beatty, J., 1979, "The propensity interpretation of fitness", Philosophy of Science, 46, p. 263-286.

Minelli, A. (2003). The Development of Animal Form. Cambridge University Press, Cambridge. Minelli, A. (2010). Evolutionary Developmental Biology Does Not Offer a Significant Challenge to the Neo-Darwinian Paradigm. In F. J. Ayala and R. Arp, eds. Contemporary Debates in Philosophy of Biology, pp. 213-226. Chichester: Blackwell Publishing.

Minelli, A. and Pradeu, T. (2014). Towards a Theory of Development. Oxford: Oxford University Press.

Monod, J., 1971 [1970], Chance and Necessity: An Essay on the Natural Philosophy of Modern Biology. Translated from the French by Austryn Wainhouse. New York, Knopf.

Morange, M., 2009, "Articulating Different Modes of Explanation: The Present Boundary in Biological Research", in Barberousse, A., Morange, M. \& Pradeu, T. (eds.)

Müller, G.B., 2007, "Evo-devo: extending the evolutionary synthesis", Nature Reviews in Genetics, 8, p. 943-949.

Nagel, E., 1961, The Structure of Science, New York, Harcourt Brace.

Neander, K., 1991, "The Teleological Notion of Function", Australian Journal of Philosophy, 69, p. 454-468.

Odling-Smee, J., Laland, K. \& Feldman, M., 2003, Niche Construction. The Neglected Process in Evolution, Princeton, Princeton University Press.

Okasha, S., 2006, Evolution and the Levels of Selection, Oxford, Oxford University Press.

Oyama, S., 2000 [1985], The Ontogeny of Information, Durham, N.C., Duke University Press. Oyama, S., 2009, "Compromising Positions : The Minding of Matter", in Barberousse, A., Morange, M. \& Pradeu, T. (eds.), p. 27-45.

O'Malley, M. A. 2013. "Philosophy and the microbe: a balancing act." Biology and Philosophy 28: $153-159$.

O'Malley, M. A., and Dupré, J. 2007. "Size doesn't matter: towards a more inclusive philosophy of biology." Biology and Philosophy, 22(2): 155-191. 
Oyama, S., Griffiths, P. \& Gray, R., eds., 2001, Cycles of Contingency, Cambridge, MA, MIT Press.

Paley, W., 1802, Natural Theology - or Evidence of the Existence and Attributes of the Deity Collected from the Appearances of Nature. $2^{\mathrm{e}}$ ed. (1827), Oxford, J. Vincent.

Pradeu, T., 2010a, Peut-on attribuer une fonction au système immunitaire?, in J. Gayon \& A. de Ricqlès (eds.) Les Fonctions : des organismes aux artefacts. Paris: Presses Universitaires de France, 261-275.

Pradeu, T., 2010b, What is an organism? An immunological answer. History and Philosophy of the Life Sciences 32: 247-268.

Pradeu T. (2011), A Mixed Self: The Role of Symbiosis in Development. Biological Theory 6(1): 80-88.

Pradeu, T., 2012, The Limits of the Self: Immunology and Biological Identity. New York: Oxford University Press

Pradeu, T., 2013, Immunity and the emergence of individuality, in F. Bouchard and P. Huneman (eds.) From Groups to Individuals: Perspectives on Biological Associations and Emerging Individuality. Cambridge, MA: MIT Press.

Pradeu T. (2017), Thirty years of Biology \& Philosophy: Philosophy of which biology? Biology \& Philosophy 32(2), 149-167

Pradeu T., Laplane L., Morange M., Nicoglou A., Vervoort M. (2011), The Boundaries of Development. Biological Theory 6(1): 1-3

Queller, D. C., and Strassmann, J. E. (2009). Beyond society: the evolution of organismality. Philosophical Transactions of the Royal Society B: Biological Sciences, 364(1533), 3143-3155. Raff, R. A. \& Raff, E. C., eds., 1987, Development as an Evolutionary Process, New York, Alan R. Liss. Inc.

Raff, R., 1996, The Shape of Life: Genes, Development and the Evolution of Animal Form, Chicago, University of Chicago Press.

Reeve, H. K. \& Sherman, P. W., 1993, "Adaptation and the goals of evolutionary research", Quarterly Review of Biology, 68, p. 1-32.

Rosenberg, A., 1985, The Structure of Biological Science, Cambridge, Cambridge University Press.

Rosenberg, A., 1997, "Reductionism Redux: Computing the Embryo", Biology and Philosophy, 12 , p. 445-470.

Rosenberg, A., 2007, "Reductionism (and Antireductionism) in Biology", in Hull, D. \& Ruse, M. (eds.), p. 120-138.

Rosenberg, A. \& McShea, D. W., 2008, Philosophy of Biology. A Contemporary Introduction, New York, Routledge.

Ruse, M., 1971, "Reduction, Replacement, and Molecular Biology", Dialectica, 25, p. 38-72.

Ruse, M., 1973, The Philosophy of Biology, London, Hutchinson University Press.

Sarkar, S., 1996, "Decoding 'Coding' - Information and DNA", BioScience, 46, p. 857-864.

Sarkar, S., 2004, "Genes encode information for phenotypic traits", in Hitchcock, C. (ed.)

Contemporary Debates in Philosophy of Science, Malden, Blackwell, pp. 259-274.

Schaffner, K., 1967, "Approaches to reduction", Philosophy of Science, 34, p. 137-147.

Smart, J. J. C., 1963, Philosophy and Scientific Realism, London, Routledge \& Kegan Paul, \& New York, Humanities Press.

Sober, E., 1984, The Nature of selection. Evolutionary Theory in Philosophical Focus, Cambridge, MA, MIT Press, $2^{\mathrm{e}}$ éd., Chicago, University of Chicago Press, 1993.

Sober, E., 1993, Philosophy of biology, Boulder, Westview Press, 2 éd., 2000.

Sober, E., 1994, From a Biological Point of View - Essays in Evolutionary Philosophy, Cambridge, Cambridge University Press. 
Sober, E., 2008, Evidence and Evolution : The Logic Behind the Science, Cambridge, Cambridge University Press.

Sober, E. (ed.), Conceptual Issues in Evolutionary Biology, Cambridge, MA, MIT Press, 1984, 1994, 2006.

Sober, E., 2011, Did Darwin write the Origin Backwards?, Amherst, New York, Prometheus Books.

Sterelny, K., 1995, "Understanding Life: Recent Work in Philosophy of Biology", The British Journal for the Philosophy of Science, 46(2), p. 155-183.

Sterelny, K., 2001, "Niche construction, developmental systems, and the extended replicator", in Oyama, S., Griffiths, P. E. \& Gray, R. D., eds., Cycles of Contingency. Developmental Systems and Evolution, Cambridge, MA, MIT Press.

Sterelny, K., 2012. The Evolved Apprentice: How Evolution Made Humans Unique. Cambridge, MA: MIT Press.

Sterelny, K. \& Griffiths, P., 1999, Sex and Death. An Introduction to the Philosophy of Biology, Chicago, Chicago University Press.

Sterelny, K. \& Kitcher, P., 1988, "The Return of The Gene", The Journal of Philosophy, 85, p. 339-60. Repris in Hull, D. \& Ruse, M., eds. 1998, p. 153-175.

Stotz, K. \& Griffiths, P., 2008, "Biohumanities: Rethinking the relationship between biosciences, philosophy and history of science, and society", Quarterly review of Biology, 83(1), p. 37-45.

Suppe, F. (ed.), 1977 [1974], The Structure of Scientific Theories, $2^{\mathrm{e}}$ éd., Urbana, University of Illinois Press.

Tauber, A.I., 1994. The Immune Self: Theory or Metaphor? Cambridge: Cambridge University Press.

Thompson, P., 1983, "The Structure of Evolutionary Theory: A Semantic Approach",

Studies in the History and Philosophy of Science 14, 215-229.

Waddington, C. H., 1940, Organisers and Genes, Cambridge, Cambridge University Press.

Waters, C. K., 1990, "Why the Antireductionist Consensus Won't Survive the Case of Classical Mendelian Genetics", in Fine, A., Forbes, M. \& Wessells, L. (eds.), Proceedings of the Biennial Meeting of the Philosophy of Science Association, vol. 1: Contributed Papers, p. 125-139. Repris in Sober, E. (ed.), 2006, p. 283-300.

Weisberg, M., 2006, Forty Years of 'The Strategy': Levins on Model Building and Idealization. Biology \& Philosophy 21, 623-645.

West-Eberhard, M. J., 2003, Phenotypic Plasticity and Evolution, Oxford, Oxford University Press.

Williams, G. C., 1966, Adaptation and Natural Selection, Princeton, Princeton University Press.

Williams, G. C., 1992, Natural Selection : Domains, Levels, and Challenges, Oxford, Oxford University Press.

Williams, M. B., 1970, "Deducing the consequences of evolution: A mathematical model", Journal of Theoretical Biology, 29, p. 343-385.

Williams, M. B., 1981, "Similarities and differences between evolutionary theory and the theories of physics", Proceedings of the Biennial Meeting of the Philosophy of Science Association (1980), Volume Two: Symposia and Invited Papers, p. 385-396.

Wilson, D. S., and Sober, E., 1989, Reviving the superorganism. Journal of Theoretical Biology, 136(3), 337-356.

Wilson, E. O., 1975, Sociobiology, the new synthesis, Cambridge, Belknap Press.

Wilson, E. O., 1978, On Human Nature, Cambridge, MA, Harvard University Press.

Wimsatt, W., 2007, Re-Engineering Philosophy for Limited Beings, Cambridge, MA, Harvard University Press. 
Wolpert, L., 1994, “Do we understand development?”, Science 266, 571-572.

Woodward, J., 2010, Causation in biology: stability, specificity, and the choice of levels of explanation. Biology \& Philosophy, 25(3), 287-318.

Wright, L., 1973, "Functions", Philosophical Review, 82(2), p. 139-168. Repris in Sober, E., ed., 1994, p. 27-47.

Wright, S., 1980, "Genic and organismic evolution", Evolution, 34, p. 825-843.

Wynne-Edwards, V. C., 1962, Animal Dispersion in Relation to Social Behavior, Edinburgh, Oliver \& Boyd. 